\title{
COMPETENCY-BASED ASSESSMENT AND THE USE OF PERFORMANCE-BASED EVALUATION RUBRICS IN HIGHER EDUCATION: CHALLENGES TOWARDS THE NEXT DECADE
}

\author{
Katherina Gallardo \\ Monterrey Institute of Technology and Higher Education, Mexico \\ E-mail: katherina.gallardo@tec.mx
}

\begin{abstract}
Rubrics are assessment guides for grading and giving feedback to students while demonstrating acquired knowledge and skills. In the last decades, rubrics have been all part of the most used learning evaluation tools in higher education. Its use is further well-related to competency-based assessment purposes. Nevertheless, criticism around design and application has been also implemented in certain reports. In order to understand rubrics' evolution, practice, benefits, and trends, a systematic literature review on rubrics' design and use has been conducted. Two databases were selected: Scopus and ProQuest Education. Two phases were determined: The first allowed to identify articles related to rubrics' design and application for almost three decades. 584 articles were found. From these, most cited articles served to give a scope of rubric evolution and trends. The second phase permitted to identify design and use of performance-based evaluation rubrics from 2009 and 2019. Five terms and Boolean combinations were used. A total of 259 articles was found. After analyzing abstracts and content, 11 open access articles on performance-oriented rubric design and application were chosen. As a result, some facts and reflections on rubric design complexity are discussed towards responding to educational challenges related to competency-based assessment contemporary demands: integration of human learning domains going beyond cognition, authenticity, and interdisciplinarity as features that characterize learning design situations, follow students' progression, educator's preparation on assessment literacy for responding to $C B A$ demands, and the involvement of experts of the work field in determining essential evaluation indicators as the main topics looking forward to the next decade.
\end{abstract}

Keywords: competency-based assessment, competency-based education, higher education, learning taxonomy, rubric design.

\section{Introduction}

Competency-based assessment (CBA) has been a relevant educational topic for almost 25 years. It is common knowledge that its complex condition comes from its roots in competencybased education $(\mathrm{CBE})$ as an integrated paradigm derived from several pedagogical approaches. Therefore, it is not possible to refer to a single entity, but rather, in practice, there are multiple ways to define and operationalize it (Farris, Demb, Janke, Kelley, \& Scott, 2009; Gervais, 2016; Meyer-Adams, Potts, Koob, Dorsey, \& Rosales, 2011; Rodriguez \& Gallardo, 2017).

The International Bureau of Education of UNESCO emphasizes the complex outcomes of a learning process that implies working within CBE, as knowledge, skills, and attitudes are all part of the learning process, rather than focusing on traditionally defined subject content. Thus, learners are expected to acquire and apply knowledge, skills, and attitudes to perform in 
Katherina GALLARDO. Competency-based assessment and the use of performance-based evaluation rubrics in higher education: Challenges towards the next decade

PROBLEMS

OF EDUCATION IN THE $21^{\text {st }}$ CENTURY Vol. 78 , No. 1, 2020

62

situations they encounter in everyday life (Escudero Escorza, 2016; Kuh, Jankowski, Ikenberry, \& Kinzie, 2014). This concern has been analyzed several times by educational authorities, in order to fulfill the needs of governments, educational institutions, and teachers for planning, implementing, and assessing performance. In fact, they are obliged to render counts to society about how close students are in reaching the standards of stated competencies. Then, CBA becomes fundamental for ensuring educational quality and accountability (Duran, EstayNiculcar, Alvarez, \& Randolph, 2015; Koh, Tan, \& Ng, 2012).

CBA is based mainly on performance and authentic assessment. It has been defined as involving observation and assessment of students' behavior while making things (Gao \& Grisham-Brown, 2011; Hancock, 2007). Students are asked to demonstrate that they are capable of transferring knowledge, executing some skills in a certain complex situation in order to solve problems, and taking decisions, or creating new alternatives within a given context. This performance is generally observed in a semi-structured context or in real-life situations where collaborative work is required. Some advantages of applying performance and authentic assessment are: (a) giving more meaning to complex learning targets; (b) assessing students' ability to make decisions and solve problems; (c) integrating knowledge, skills, and attitudes into assessment and feedback; (d) giving the learning processes an important role rather than only focusing on solutions and products; and (e) being consistent with philosophical and pedagogical $\mathrm{CBE}$ basics.

Most of the time, discussions about implementing CBA focus on how to guarantee that performance assessment would be done with feasibility and validity, without depending just on standardized tests (Barber \& Phillips, 2000; Duckworth \& Yeager, 2016). Instead, alternative and authentic assessment practices are required (Caliskan \& Kasikci, 2010). Thus, some alternative assessment practices emerge and are used by teachers: project-based learning, challenge-based learning, portfolio, etc. Nevertheless, poor/fast teacher training and several misunderstandings while designing and interpreting data through these assessment mechanisms could be considered weak areas of CBA implementation.

\section{Competency-based Assessment: Challenges in Times of Educational Change}

Almost all societies are living in a period of rapid and disruptive educational development. Having access to a high-quality education that considers human beings' main concerns and needs of development besides simple disciplinary knowledge, becomes part of worldwide priorities to be solved in the future. European, Asian, Australian and Latin-American countries are modifying their educational scope structurally in order to introduce CBE at different levels: primary, secondary, vocational and tertiary education (Boukhentache, 2016; Voronov, Chasovskykh, Popov, Anyanova, \& Krainova, 2015).

Even if there has been a high interest in implementing CBE over these years as one possible way to give answers to the Economy and Society Knowledge demands (Carrillo, 2015; Slaus, 2013), there are aspects that are not totally solved around how to assess students' performance with accuracy and feasibility, in a world that has explained learning results based simply on grades and statistics for years. Indeed, identifying and recognizing CBA advantages does not automatically change traditional learning assessment practices. However, we cannot deny that the scope is changing progressively.

For instance, the Australian Learning and Teaching Council has made some relevant assessment decisions (Boud, 2009) related to strengthen CBA toward the year 2020: (a) assessment is a central feature of teaching and the curriculum; (b) it is an accurate way to understand how students learn and what students achieve; and (c) it is one of the most significant influences on students' experience, so it is mandatory to improve assessment practices due to its huge impact on learning quality. 
Another example of the CBA evolution is taking place in Bangladesh (Roy, 2016). The ways to improve the quality of basic education by evaluating learning achievement in terms of terminal competencies, considering different school systems based on a nationally representative sample, and examining the relationship between learning achievement and selected students' characteristics, such as socioeconomic status, school-related variables, and receipt of extra educational inputs. Thus, the government is applying different assessment strategies rather than just examining and scoring content retention through standardized tests.

Moreover, it is understood that CBA not only has challenges to face and solve in the implementation phase but also a number of issues to address for gaining credibility (Barber \& Phillips, 2000; Ellis et al., 2015). Among these main challenges, the most relevant are:

- Revising competencies and academic programs to make sure CBA is conducted with coherence

- Deciding processes, terms, and parameters related to competence accomplishment along with each program

- Counting on internal and external experts' support for establishing valuable tasks and projects

- Establishing collegiate agreements for the performance-based evaluation rubric

- Selecting meaningful standards for assessing and giving feedback.

Thus, it can be affirmed that in the eye of this hurricane of educational changes toward adopting CBA, big efforts must be made to deliver a high-quality assessment process.

\section{Rubric: More than 20 Years of Research}

The operationalization of CBA into applied strategies and the use of different tools for observing, collecting, and giving feedback about students' performance have been studied and enriched over the past few years. Undoubtedly, one of the most-used performance-assessment tools is rubric. Its main intention is to describe what students are expected to demonstrate through their performance. This is possible as long as a rubric contains a clear description of intended and connected actions corresponding to the statement of criteria, and the standards and levels of performance expected from the related competencies (Jonsson, 2014).

Rubrics for learning assessment purposes have been studied for several years. From the first discussion about its use within holistic evaluation processes (Grubb, 1981), almost six hundred articles have been published to discuss new knowledge on the design or use of this tool in different disciplines (Elsevier, 2019). Thus, rubric has passed through a rapid evolution process over the past few years (Bharuthram \& Patel, 2017).

Rubric design has challenged educators and educational researchers to study, understand and create different ways to answer one of the most difficult aspects of the learning process: giving judgments about performance. These judgments can come from different actors involved in the educational process, even from experts in the field of study who are asked to give their opinion about students' performance. Then, rubric is expected to be a simple, clear, accurate, consistent and flexible tool for collecting diverse points of view related to certain performance criteria, in a holistic or an analytic way (Mertler, 2001; Panadero \& Jonsson, 2013).

Many efforts have been made lately to establish norms to improve rubrics' design and use from the technical point of view. Curiously, this norming trend comes from engineering education initiatives. For instance, Goldberg (2014) discussed some common problems while designing a rubric: lack of consistency and parallelism, detection of "orphan" and "widow" words and phrases, redundancy in descriptors, inconsistency in focus of qualifiers, limited routes to partial credits, unevenness in incremental levels of performance and inconsistencies across the suite of rubrics. Additionally, Schoepp, Researcher, and Kranov (2018) established 
Katherina GALLARDO. Competency-based assessment and the use of performance-based evaluation rubrics in higher education: Challenges towards the next decade

PROBLEMS

OF EDUCATION

IN THE $21^{\text {st }}$ CENTURY Vol. 78 , No. 1,2020

64 consisted of document preparation; rubric review; initial reading and scoring of one learning outcome; initial sharing/recording of results; initial consensus development and adjusting of results; initial reading and scoring of remaining learning outcomes; the reading and scoring of remaining transcripts; sharing/recording results; and the development of consensus and adjustment of results.

Nevertheless, in the literature, profound discussions about the need for alignment among educational model features are rarely found, nor are performance-assessment principles and rubric design parameters, especially in terms of CBA.

\section{Research Problem}

This research intention was to have a wide perspective on one of the most-used performance-assessment tools: the rubric. It has become a powerful way to assess and give feedback to students in the past few years (Jonsson, 2014; Lasater, 2006; Reddy \& Andrade, 2010). Nevertheless, several positive as well as negative ideas have been discussed about its design and use in different disciplines. It could be relevant to understand practices, weak areas as well as challenges for the next years in terms of its use. The two researched questions that guided this research were: What can it be said and understood about rubric evolution in the last decades? and What are the main challenges about performance-based evaluation rubric design and application?

\section{Research Methodology}

\section{General Background}

The aim was to understand rubrics' design and use in tertiary education in general and for performance assessment purposes in particular while CBE model is getting used and expanded worldwide. This aim involved a Systematic Literature Review (SLR). This methodology aims to identify, evaluate and summarize the findings of all relevant individual studies, thereby making available evidence more accessible. The process includes elements such as (1) start by a research question; (2) specify the search strategy and criteria for inclusion and exclusion of studies; (3) identify, describe and synthesize relevant research. The methodology enables the incorporation of quantitative, qualitative, and mixed methods studies as long as the importance of both the intellectual quality of the original studies and the context, culture, and values relevant in evaluation studies are included (Caracelli \& Cooksy, 2013).

Two abstract and citation database of peer-reviewed literature databases were selected: Scopus and ProQuest Education. For the searching process five keywords were chosen according to the research interest: Rubrics, Competency-based education, Competency-based assessment, Performance Assessment, and Competence. It was determined that "and" was the right Boolean command for this search purpose. The sample then was determined by the search process run on these databases combining main and subsequence keywords.

\section{Instrument and Procedures}

The researcher counted on access to make searches in two databases through the university digital library system (https://biblioteca.tec.mx/basesdedatos). Hereby, the phases and steps followed for the analysis.

Phase I: (1) Enter to the databases; (2) use of the keyword "Rubric" in the title of the 
Katherina GALLARDO. Competency-based assessment and the use of performance-based evaluation rubrics in higher education: Challenges towards the next decade

article; (3) select a period of 23 years (1996-2019) for search purposes, as 1996 was identified Vol. 78 , No. 1, 2020 as the year where the level of scientific production in this topic started to increase.

Phase II: (1) Enter to the databases; (2) use of five selected words for the search purpose: Rubric as the main word in the title of the article and Competence, Competency-based education, Competency- based assessment and Performance assessment as complimentary words in the title, keywords and abstract. The Boolean combination "and" was used for filter of search: Rubric and Competency-based education in the title, abstract and keywords, Rubric and Competence in the title, Rubric and Competence-based assessment in the title, abstract and keywords, Rubric and Competence-based assessment in the title, Rubric and Performanceassessment in the title, abstract and keywords and Rubric and Performance-assessment in the title identify; (3) gather systematically all the findings in independent datasheets for making searches and select specifically the articles corresponding to research purpose.

\section{Data Analysis}

The database was organized in an Excel file with a total of 11 independent sheets. In each sheet, the list of collected data was registered. The headings for storing systematically each article data were: Authors, Author(s) ID, title, year, source title, volume issue, article number, page start, page end, page count, cited by, DOI, link, affiliations, abstract, author keywords, document type, publication stage, access type. These fields were analyzed for ensuring that any article was duplicated. A counting table was designed in a complimentary independent sheet for knowing exactly how many articles were found in this first moment (Table 1).

\section{Table 1}

SLR strategy and criteria for inclusion and exclusion of studies

\begin{tabular}{|c|c|c|c|c|}
\hline $\begin{array}{l}\text { Phases of } \\
\text { research }\end{array}$ & Database & Main word & Complimentary words & Amount \\
\hline Phase I & Scopus \& ProQuest & Rubric (TIT) & $\mathrm{D} / \mathrm{A}$ & 584 \\
\hline \multirow{13}{*}{ Phase II } & Scopus & Rubric (TIT) & Other four keywords & 153 \\
\hline & ProQuest & Rubric (TIT) & Other four keywords & 112 \\
\hline & Scopus \& ProQuest & Rubric (TIT) & Other four keywords & *259 \\
\hline & Scopus & Rubric (TIT) & $\begin{array}{l}\text { Competency-based } \\
\text { education (TKA) }\end{array}$ & 9 \\
\hline & ProQuest & Rubric (TIT) & $\begin{array}{c}\text { Competency-based } \\
\text { education (TKA) }\end{array}$ & 7 \\
\hline & Scopus & Rubric (TIT) & Competence (TIT) & 10 \\
\hline & ProQuest & Rubric (TIT) & Competence (TIT) & 2 \\
\hline & Scopus & Rubric (TIT) & $\begin{array}{l}\text { Competency-based } \\
\text { assessment (TKA) }\end{array}$ & 6 \\
\hline & ProQuest & Rubric (TIT) & $\begin{array}{l}\text { Competency-based } \\
\text { assessment (TKA) }\end{array}$ & 7 \\
\hline & Scopus & Rubric (TIT) & $\begin{array}{c}\text { Performance assessment } \\
\text { (TKA) }\end{array}$ & 141 \\
\hline & ProQuest & Rubric (TIT) & $\begin{array}{c}\text { Performance assessment } \\
\text { (TKA) }\end{array}$ & 103 \\
\hline & Scopus & Rubric (TIT) & $\begin{array}{c}\text { Performance assessment } \\
\text { (TIT) }\end{array}$ & 20 \\
\hline & ProQuest & Rubric (TIT) & $\begin{array}{c}\text { Performance assessment } \\
\text { (TIT) }\end{array}$ & 3 \\
\hline
\end{tabular}

Note: TIT means title, TKA means title, keywords and abstract, D/A means does not apply

* 6 articles were deleted: 3 duplicates, and 3 products not recognized as research articles 
Katherina GALLARDO. Competency-based assessment and the use of performance-based evaluation rubrics in higher education: Challenges towards the next decade

PROBLEMS

OF EDUCATION

IN THE $21^{\text {st }}$ CENTURY

Vol. 78 , No. 1,2020

\section{Research Results}

\section{Phase I Results}

The first analysis of the 584 collected articles related to rubric design and application from the title of these works, permitted a first glance of their origins: these articles have been published mainly in these countries: United States (31\%), Spain (12\%), Australia (10\%), Canada $(8 \%)$ and Turkey (7\%), United Kingdom (6\%), Netherlands (5\%) Japan (5\%). Other countries have $2 \%$ or less. Besides, faculty highly involved in the research of this topic are affiliated to Universidad Autónoma de Madrid, Purdue University, University Albany State of New York, Universidad Jaume and Texas A\&M University.

From the 584 articles, 29 were chosen by their high number of citations as a criterion that might take the researcher to read the most popular publications in this subject area along last years. This permitted to revise carefully the content, orientation, results, and discussions around rubric application.

In this phase of the research, it was also possible to map the different disciplines involved in the study of rubric design and application besides social science and education. It was interesting to find that many articles were published by researchers of other disciplines different from social studies, such as engineering, health science, business, agriculture, etc.

Besides, it was detected first that most of the articles emphasize the advantages that rubrics bring to diagnostic, formative, and summative assessment, specifically on certain features such as utility and transparency while rubric is used for giving feedback. Besides, its power of making students reflect around self-assessment and self-efficacy practices is being discussed (O’Brien, Franks, \& Stowe, 2008; Smit, Bachmann, Blum, Birri, \& Hess, 2017; Yune, Lee, Im, Kam, \& Baek, 2018).

Nevertheless, some misunderstandings and criticism around rubric design process are also debated. For instance, Tigelaar and Janssen (2012) reported some dilemmas that arose while designing rubrics for assessing science student teachers' performance: fully detailed criteria against open-ended description; the importance given to the theoretical domain against practical knowledge application; the establishment of novice against expert performance level as point of departure for performance explanation; the involvement for validation purposes of only teachers against including some stakeholders, among others. Moreover, Eshun and OseiPoku (2013) and Jonsson and Svingby (2007) highlighted some disadvantages and criticisms of designing and using rubrics: the exclusive and excessive use of rubrics for assessment purposes, a lack of guidance for making judgments through rubric levels, the absence of a validity and reliability process, were among the main problems identified. Table 2 contains an overview and summary of Phase I synthesis of rubric research and evolution in the last decades. 
Katherina GALLARDO. Competency-based assessment and the use of performance-based evaluation rubrics in higher education: Challenges towards the next decade

Table 2

Rubric evolution based on a Scopus and ProQuest analysis of articles about rubric design and application over the past 23 years

\begin{tabular}{|c|c|c|c|c|c|}
\hline & $1996-2000$ & 2001-2005 & 2006-2010 & 2011-2015 & 2016-2019 \\
\hline $\begin{array}{l}\text { Number of } \\
\text { scientific } \\
\text { published } \\
\text { articles }\end{array}$ & 23 & 32 & 79 & 188 & 262 \\
\hline $\begin{array}{l}\text { Disciplines } \\
\text { besides } \\
\text { Social } \\
\text { Science and } \\
\text { Education }\end{array}$ & $\begin{array}{l}\text { Pharmacology } \\
\text { Physics } \\
\text { Veterinary }\end{array}$ & $\begin{array}{l}\text { Mathematics } \\
\text { Medicine } \\
\text { Nursery } \\
\text { Neuroscience }\end{array}$ & $\begin{array}{l}\text { Earth Science } \\
\text { Economics } \\
\text { Energy } \\
\text { Engineering }\end{array}$ & $\begin{array}{l}\text { Chemistry } \\
\text { Computer } \\
\text { science } \\
\text { Dentistry }\end{array}$ & $\begin{array}{l}\text { Agriculture } \\
\text { Biochemistry } \\
\text { Business } \\
\text { Creative } \\
\text { thinking }\end{array}$ \\
\hline $\begin{array}{l}\text { Parallel } \\
\text { emergent } \\
\text { topics related } \\
\text { to rubric } \\
\text { design and } \\
\text { application }\end{array}$ & $\begin{array}{l}\text { Formative } \\
\text { assessment } \\
\text { Feedback }\end{array}$ & $\begin{array}{l}\text { Validity } \\
\text { Reliability } \\
\text { Quantification } \\
\text { analysis } \\
\text { Scoring } \\
\text { Design } \\
\text { recommendations }\end{array}$ & $\begin{array}{l}\text { Self-assessment } \\
\text { Self-efficacy } \\
\text { Teaching } \\
\text { Inter-rater } \\
\text { and intra-rater } \\
\text { reliability }\end{array}$ & $\begin{array}{l}\text { Higher education } \\
\text { Peer } \\
\text { assessment } \\
\text { Reasoning skills } \\
\text { Writing skills } \\
\text { Factor analysis }\end{array}$ & Metacognition \\
\hline Criticism & $\begin{array}{l}\text { Risk of exclusive } \\
\text { use }\end{array}$ & $\begin{array}{l}\text { Lack of validity and } \\
\text { reliability } \\
\text { Right number of } \\
\text { criteria }\end{array}$ & $\begin{array}{l}\text { Time consuming } \\
\text { design and use } \\
\text { Intolerance to } \\
\text { change } \\
\text { Converting } \\
\text { scales to scores }\end{array}$ & $\begin{array}{l}\text { Redundancy } \\
\text { Inconsistency in } \\
\text { focus qualifiers }\end{array}$ & $\begin{array}{l}\text { Students lack } \\
\text { of participation } \\
\text { in design }\end{array}$ \\
\hline
\end{tabular}

\section{Phase II Results}

From the 259 articles, 11 open access research articles were chosen for a deeper analysis according to SLR methodology. Their contents have been considered of high involvement with performance-based evaluation design and application rubric topic. First, a summary of main aspects of each article was organized in a table. Then, three questions were asked to extract relevant information about performance-oriented rubric research: (1) what are the main interests while studying performance-oriented rubric design and use? (2) what kind of data are these studies collecting for analysis; (3) what is the proposal for future research? Finally, some facts, as well as some missing aspects according to competency-based assessment and performance-assessment demands, are discussed.

The main aspects related to the 11 chosen articles were collected. It was taking into consideration: Author(s) and year of publication, the academic level where the research was conducted, the subject area or discipline, focus of the research problem, methodology, main results and suggested future research. The information is organized in table 3 following a chronological order. 
Katherina GALLARDO. Competency-based assessment and the use of performance-based evaluation rubrics in higher education: Challenges towards the next decade

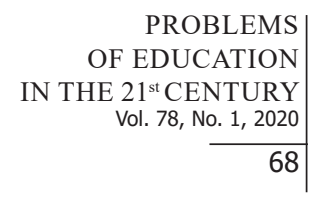

.

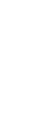

a

के

ङे

है
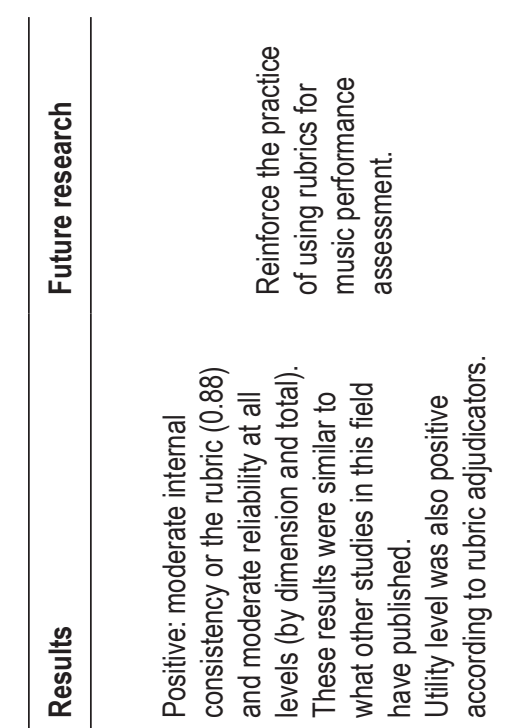

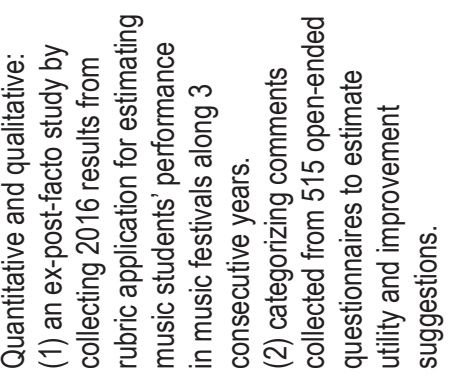

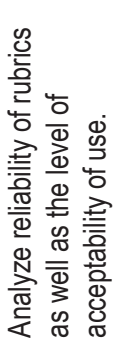

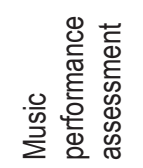

$\frac{1}{8} \stackrel{n}{\circ}$

엉

들 兽竡

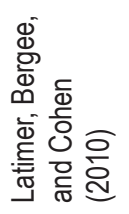

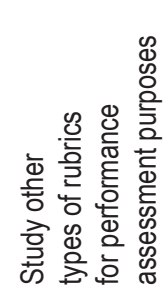

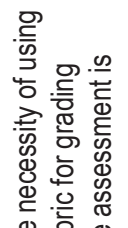

을 윤

बं

잉 행ㅎㅀ을

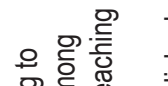

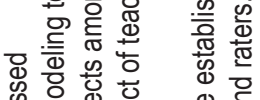

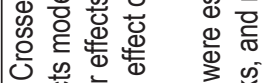

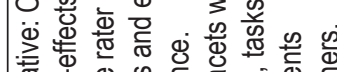

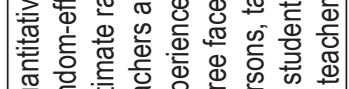

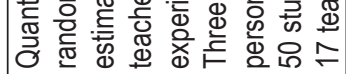

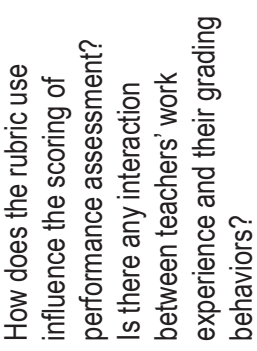

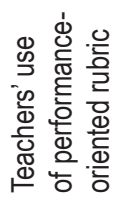

$\frac{0}{5}$
$\frac{0}{5}$
$\frac{5}{0}$

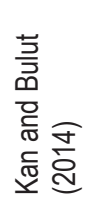

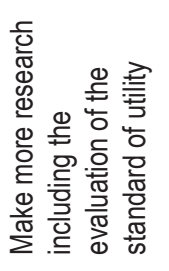

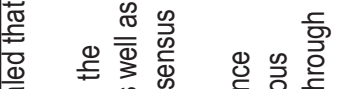

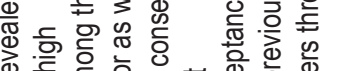

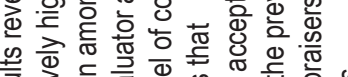
管

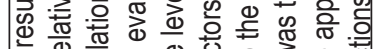

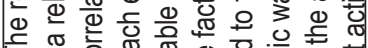

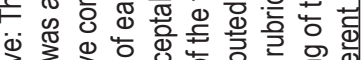
政

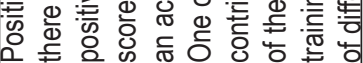

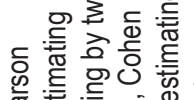

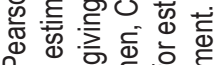
일 蛋 青 $\frac{10}{2}$ क

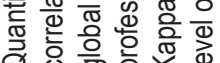
욤 $\stackrel{0}{\underline{\underline{t}}} \subseteq$

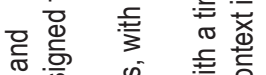
震 责

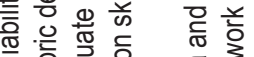
힐 ब 空

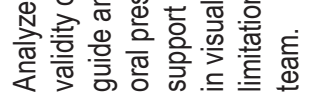

$\overline{\frac{\pi}{3}}$

曾

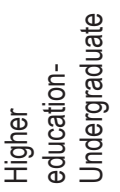

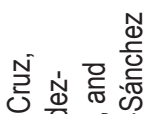

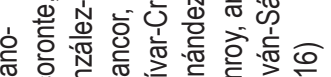

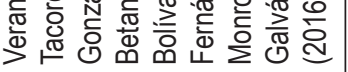


PROBLEMS

OF EDUCATION

IN THE $21^{\text {st }}$ CENTURY

Vol. 78 , No. 1, 2020

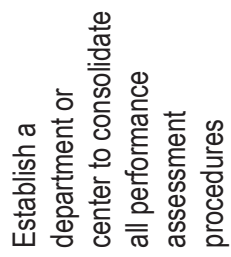

69
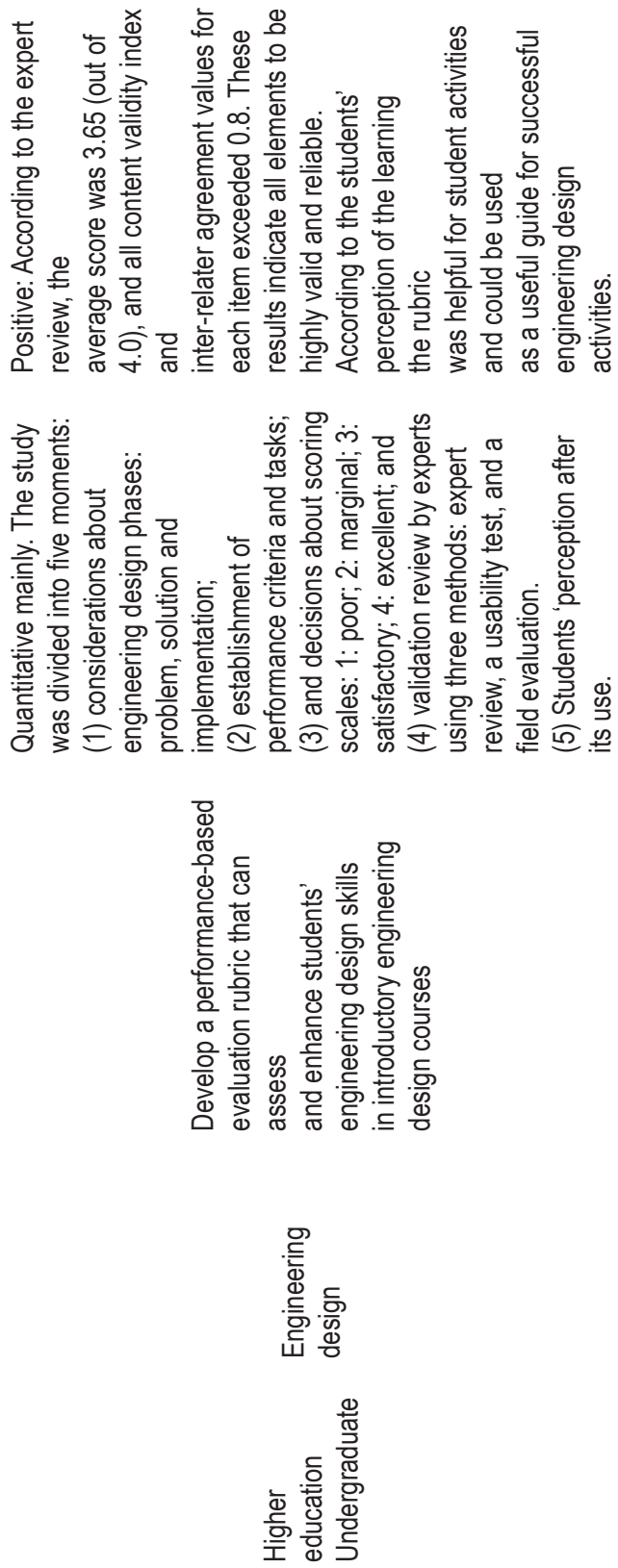

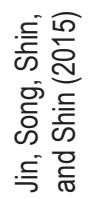
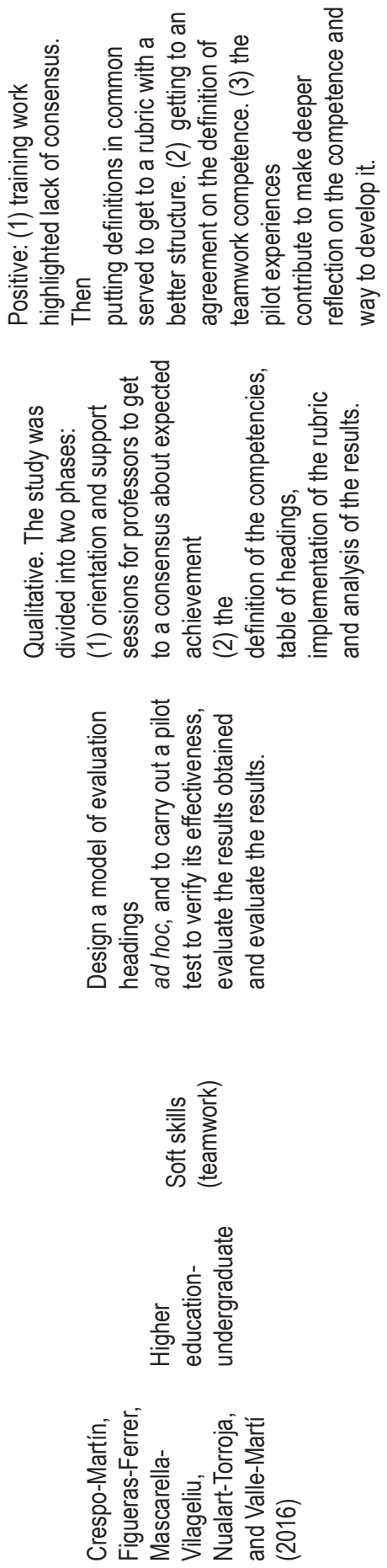
Katherina GALLARDO. Competency-based assessment and the use of performance-based evaluation rubrics in higher education: Challenges towards the next decade

PROBLEMS OF EDUCATION IN THE $21^{\text {st }}$ CENTURY Vol. 78, No. 1, 2020
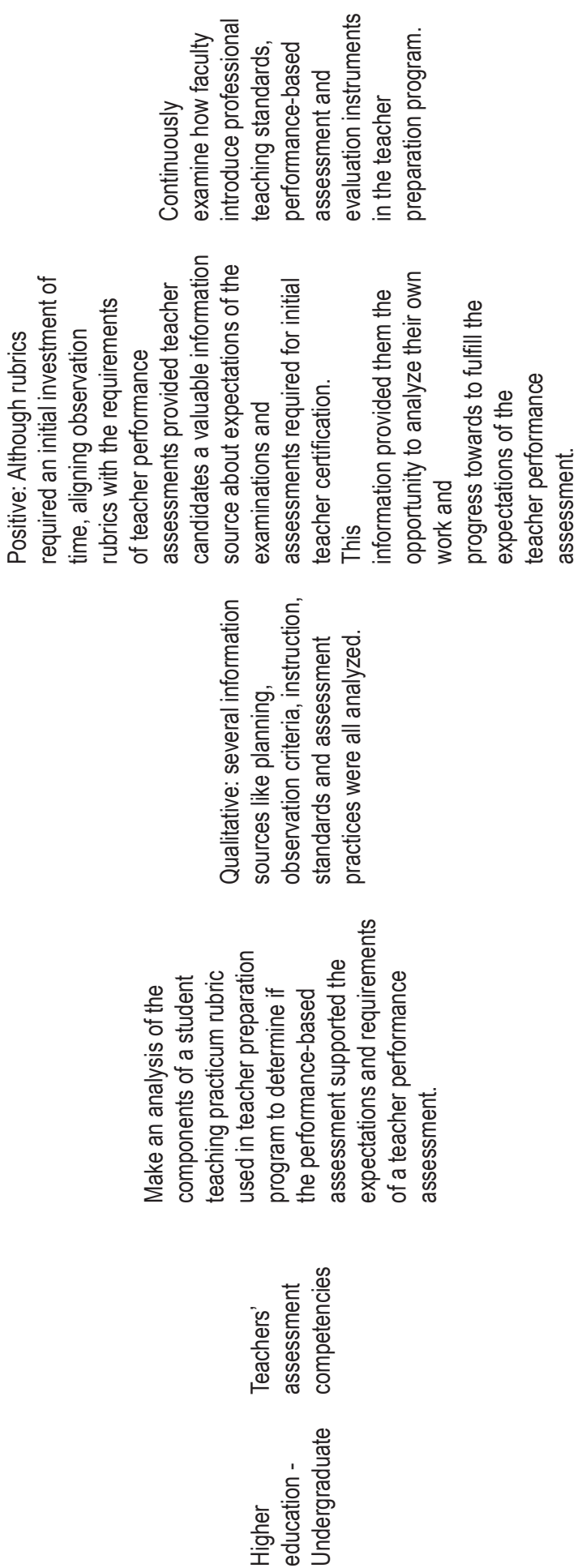

$\frac{\text { ํㅗㅇ }}{\text { ํ. }}$ 
Katherina GALLARDO. Competency-based assessment and the use of performance-based evaluation rubrics in higher education:

PROBLEMS

OF EDUCATION

IN THE $21^{\text {st }}$ CENTURY

Vol. 78, No. 1, 2020

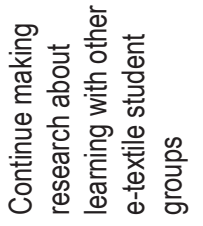

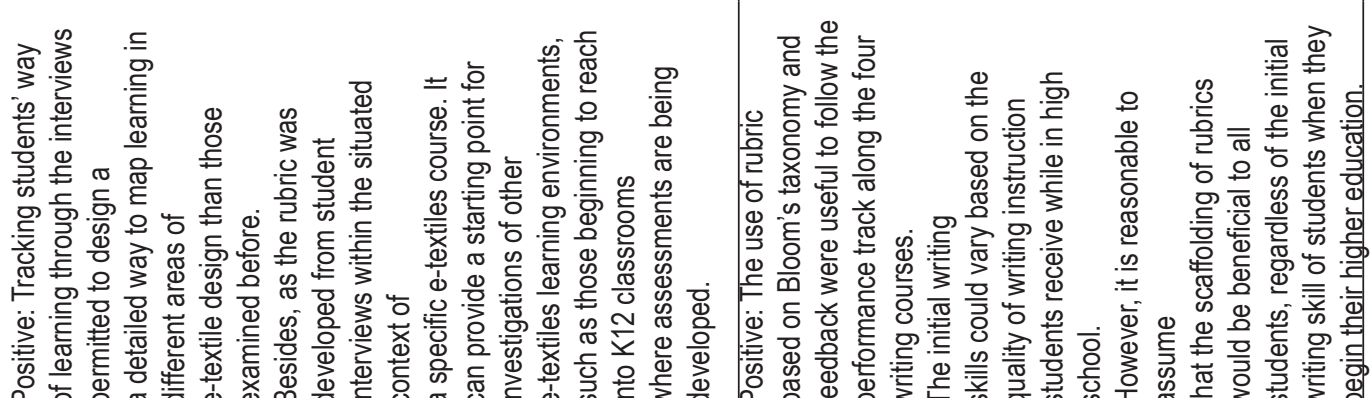

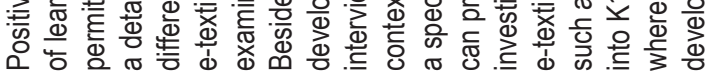

$\ll$ 융 음

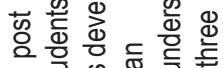

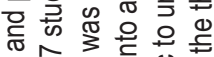

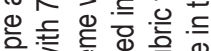

बi

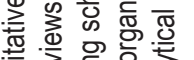

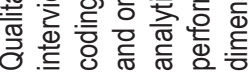

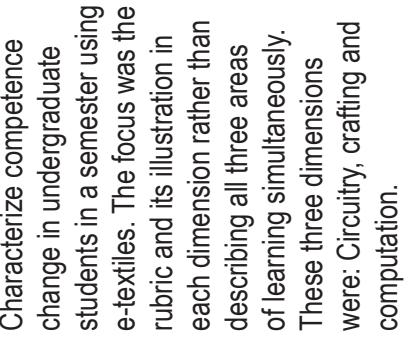

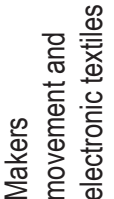

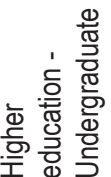

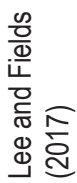

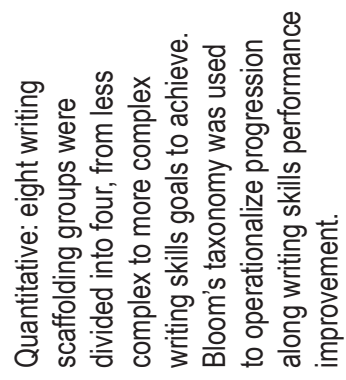

음 은

응 은 등

은 은 을

융 0

岕要言

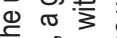

声

응 흥 은

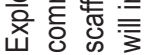

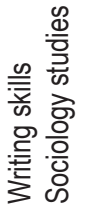

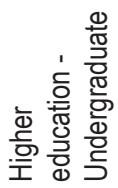

은

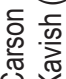


Katherina GALLARDO. Competency-based assessment and the use of performance-based evaluation rubrics in higher education: Challenges towards the next decade

PROBLEMS

OF EDUCATION

IN THE $21^{\text {st }}$ CENTURY

Vol. 78 , No. 1, 2020

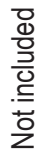

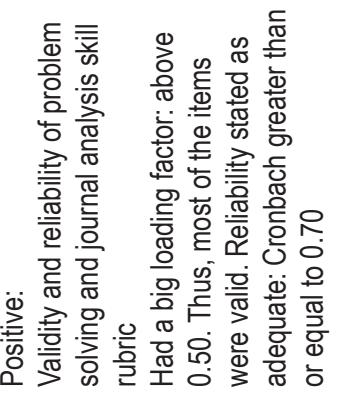

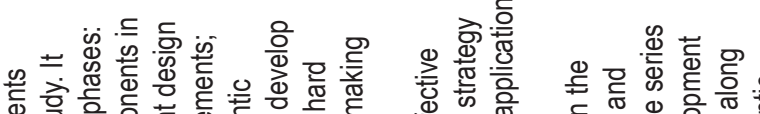



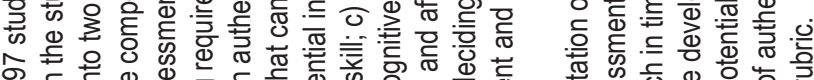

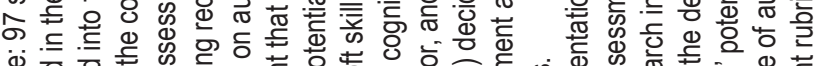

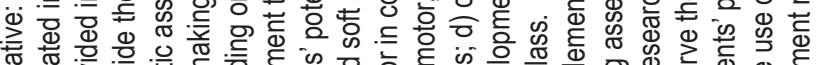

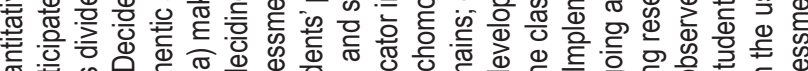

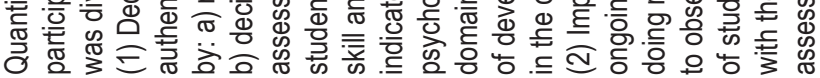

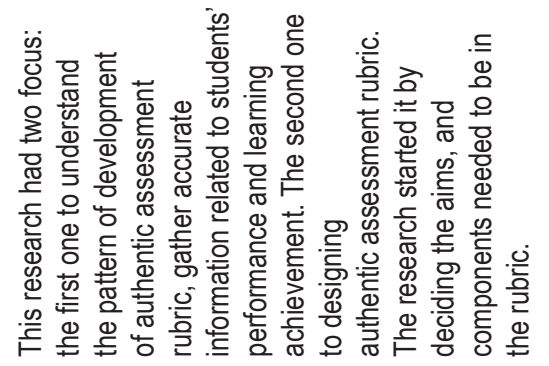

증 흥
음
음

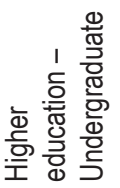

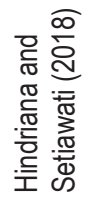
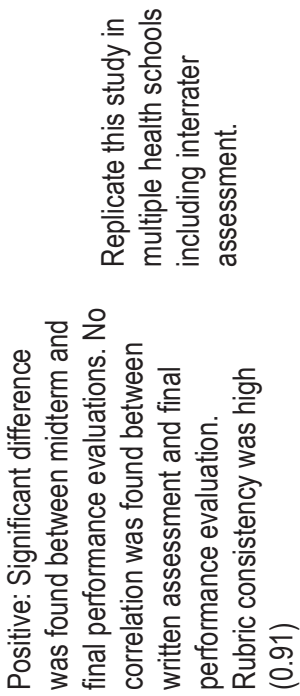

焉弯

둔

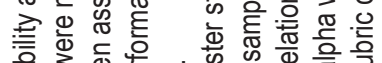

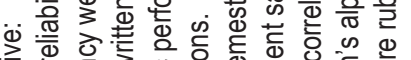

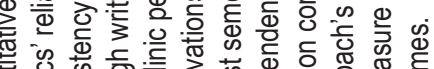

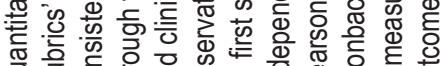

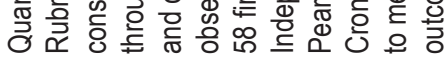
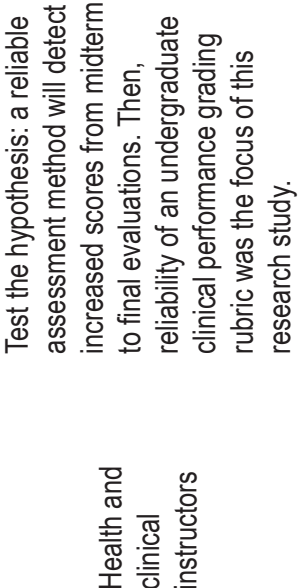

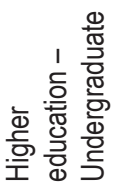

$$
\begin{aligned}
& \text { o } \\
& \stackrel{0}{0} \\
& \frac{0}{2} \\
& \frac{0}{2}
\end{aligned}
$$


Katherina GALLARDO. Competency-based assessment and the use of performance-based evaluation rubrics in higher education: Challenges towards the next decade

PROBLEMS

OF EDUCATION

IN THE $21^{\text {st }}$ CENTURY

Vol. 78, No. 1, 2020

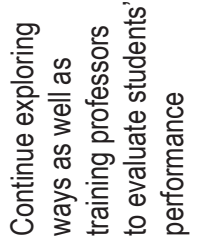

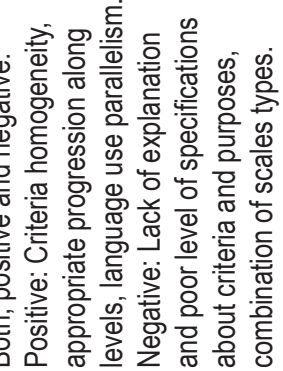

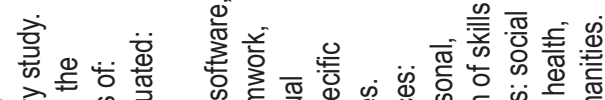

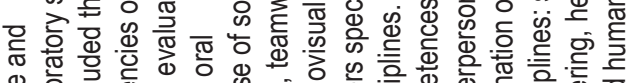

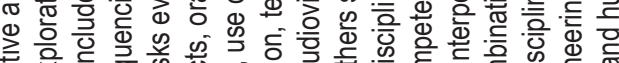

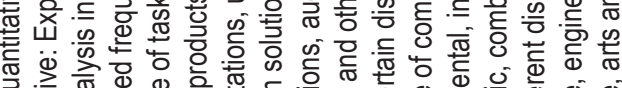

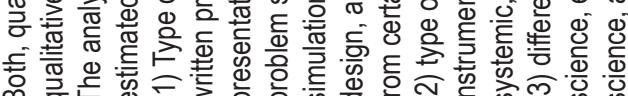

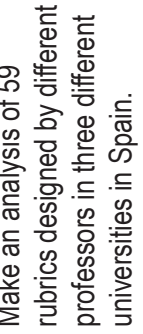

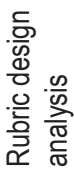

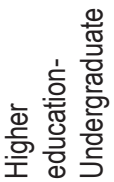

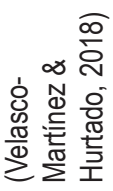

73 
Katherina GALLARDO. Competency-based assessment and the use of performance-based evaluation rubrics in higher education: Challenges towards the next decade

PROBLEMS

OF EDUCATION IN THE $21^{\text {st }}$ CENTURY Vol. 78 , No. 1,2020

What are the main interests while studying performance-based evaluation rubric design and use? It could be affirmed that there are two main research interests: In the first place, reliability and validity as a way to ensure rubric quality. The goal refers, on the one hand to consistency and stability of the instrument. On the other hand, to the consensus from experts to select criteria, describe expected performance levels and agree upon meaning. Indeed, this interest has been considered relevant since 2001 (Table 1). It is possible to infer from Latimer, Bergee and Cohen (2010), Jin, Song, Shin and Shin (2015) and Kopp (2018) that performancebased evaluation rubrics are instruments with high possibilities on supporting reliable and valid assessment process for observing and judging students' performance advances.

In the second place, the capabilities and preparation of educators for designing rubrics. Undoubtedly, rubric design is a complex task that involves decision making starting by the understanding on student's profile, ways to promote progression along the educational program, the context and conditions of the educational scenario, the task purpose, previously defined competencies and standards, authenticity of tasks, among other variables. Velasco-Martínez \& Tójar Hurtado (2018) concluded after a wide analysis of diverse rubrics for different disciplines assessing needs that there is a latent risk educator that could have designed rubrics without any previous training. Thus, it is recommended to establish explicit and clear criteria to ensure rubrics design quality. Therefore, it seems advisable from the analysis that participation in workshops of design and use of rubrics in order to train teachers for an adequate evaluation with rubrics is highly recommended.

What kind of data are these studies collecting for analysis? From the 11 articles analyzed, almost all of them presented quantitative data analysis. This information was used for demonstrating through conventional statistics the level of reliability and correlation of rubrics results in contrast to grading. Cronbach's alpha and Pearson correlation coefficient were the most used measures to make judgments about rubrics quality.

Nevertheless, results from studies based on mixed methods or qualitative methodology gave information about the design process and perceptions of users rather than results of its application. These studies focused on decision making, consensus, and proposed different ways of making rubrics useful. For instance, in the study of Brown (2017) as a proposal for improving performance-based evaluation rubric design started by the examination of certain documents and procedures that guide educators' performance. In the case of Lee and Fields' study (2017) the main information source for rubric design was students' perception. Neither theoretical contents, nor teachers' expectations but the way students perceived their performance advances in three different tasks along a semester were taken into consideration.

What is the proposal for future research? Most researchers' point of view agreed that the application rubrics in other scenarios as well as the exploration of new proposals for rubric design are the most common recommendations. Besides, educators training and practice for designing and improving rubrics should be also considered for future research.

In the opinion of the researcher, it was unexpected to find just a very few ideas for future research while performance-based evaluation rubrics is a complex vast topic with a wide spectrum of educational research possibilities. This situation derived to certain aspects of discussion.

\section{Discussion}

Results from this research permitted to confirm that rubrics design is a topic of upward interest in the educational process around the world. The rise of interest from decade to decade doubled and tripled the number of studies published in recognized indexed journals. Thus, SLR permitted to have a holistic view of rubric evolution for almost three decades as well as a current view around relevant issues in the last decade about its design, application and quality insurance for performance-assessment purposes. 
One of the main results from the SLR is the confirmation of the importance of the design and use of rubrics as a matter of studies in different disciplines' educational processes as well as soft skills assessment interests. Undoubtedly, the popularization of rubrics as a tool for guiding, observing and measure students' progress in different knowledge areas and task is increasing.

Besides, it was confirmed through the specific analysis in Phase 2 that higher education is the education level where most of these studies are taking place. Nevertheless, the advances in rubric studies related to complementary topics of CBA and performance assessment are quite weak at this time. Indeed, just a few isolated efforts could be found through SLR that give a deeper understanding on how to integrate in rubrics design elements of authenticity and complexity of learning scenarios (Hindriana \& Setiawati, 2018), full integration of other domains going further cognition (Lee \& Fields, 2017) or assessment literacy focused on performance-based evaluation rubrics design (Velasco-Martínez \& Hurtado, 2018).

As a matter of fact, there are some educational challenges around CBA and performance assessment that educators, as well as educational researchers, would need to identify for the next decade related to the study of CBA and performance-based evaluation rubrics:

(1) Integration of cognitive, psychomotor, social and affective domains. Even if almost all studies refer to performance-based evaluation rubrics as powerful tools to observer capabilities and executing some skills, very few of them go beyond integrating elements distinct from the cognitive domain. This fact could be considered contradictory as psychomotor, social and affective domains need to be integrated into students' performance in complex situations based on competencies development (Escudero Escorza, 2016; Kuh et al., 2014).

(2) Comprehension of the authentic complex situation where performance assessment takes place. Authentic complex situations (Gao \& Grisham-Brown, 2011; Hancock, 2007) need to be comprehended to clarify the indicators that integrate a performancebased evaluation rubric. This is even more important when problems or situations to be solved integrate interdisciplinary activities. As one of the most important performance assessment goals is giving information on the process of gaining expertise, then the identification and operationalization of the main variables and circumstances that configure a complex situation to be solved are critical pieces of information for learners and educators.

(3) Definition of expected performance reached level according to students' progress. From the 11 studies, just Brown (2017) and Lee \& Fields (2017) took explicit consideration of this variable related to one of CBA main purpose. Indeed, performance-based evaluation rubrics should permit to understand the way students progress from one time to another. This is possible when some consensus about the expectations on students' performance level is previously established.

(4) Assessment literacy in educator's preparation for CBA demands. From the 11 studies, just one of them (Velasco-Martínez \& Hurtado, 2018) focused on the understanding of how educators, specifically professors, design rubrics. The report revealed among the most relevant weakness aspects: the lack of explanation, poor level of specifications about criteria and purposes, and possible misunderstandings in the selection of scales. As educators are the main responsible for instrumental assessment practices in the classroom, it would be necessary to identify good practices while taking decisions for rubric design purpose.

(5) Participation of external experts in rubric design. CBA features of authenticity involve challenging situations from the work field (Gao \& Grisham-Brown, 2011; Hancock, 2007). Students are exposed intentionally to these situations to gain expertise and improve their level of performance in certain competencies. Then, it would be appropriate to take opinions from experts of diverse disciplines as 
Katherina GALLARDO. Competency-based assessment and the use of performance-based evaluation rubrics in higher education: Challenges towards the next decade

\author{
PROBLEMS \\ OF EDUCATION \\ IN THE $21^{\text {st }}$ CENTURY \\ Vol. 78, No. 1, 2020 \\ 76
}

employers and seniors while designing a performance-based evaluation rubric as well as when applying and giving feedback to students.

\section{Conclusions}

Rubrics have evolved in the last years as a powerful support tool to make judgments about students' learning in several disciplines. The amount of studies related to rubric design, application and reliability for ensuring high level of quality and utility has increased globally. The frequency of the studies related to this evaluation tool is concentrated by now on higher education mainly.

Rubric design features have been changing according to the educational model and assessment needs. In the case of this study, performance-based evaluation rubrics have been considered a relevant topic as $\mathrm{CBE}$ and $\mathrm{CBA}$ have transformed higher formative education scope in many countries around the world.

In the framework of CBA and performance assessment settings, a SLR took the researcher to focus on 11 articles related to the design and use of performance-based evaluation rubric. The analysis reflected that almost the same research topics are also studied, even if CBE scope would have conducted researchers to incorporate other subjects such as integration of human learning domains going beyond cognition, authenticity and interdisciplinarity as features that characterize learning design situations, follow students' progression along their higher education preparation, the involvement of experts of the work field in determining essential evaluation indicators or assessment literacy in educator's preparation for CBA demands. These aspects need to be considered in the next decade of performance-based evaluation rubrics studies.

\section{Acknowledgements}

The author would like to acknowledge the financial support of Novus Grant - Tecnologico de Monterrey, Mexico, in the production of this work.

\section{References}

Barber, M., \& Phillips, V. (2000). Big change questions: Should large-scale assessment be used for accountability? Journal of Educational Change, 1(3), 277-281. http://dx.doi. org/10.1023/A:1010064308012

Bharuthram, S., \& Patel, M. (2017). Co-constructing a rubric checklist with first year university students: A self-assessment tool. Journal of Applied Language Studies, 11(4), 35-55. http://dx.doi. org/10.17011/apples/urn.201708073430

Boud, D. (2009). Assessment 2020: Seven propositions for assessment reform in higher education. Education and Training, 330-333. https://doi.org/10.1200/JOP.2011.000236

Boukhentache, S. (2016). Operationalization of competency-based approach: From competency-based education to integration pedagogy. Arab World English Journal, 7(4), 439-452. https://ssrn.com/ abstract $=2898657$

Brown, C. S. (2017). Aligning a performance-based observation rubric to support a teacher performance assessment. Journal of Interdisciplinary Studies in Education, 5(2), 11-25. http://search.ebscohost. com/login.aspx?direct=true \&db=ehh\&AN=125891944\&site=ehost-live

Caliskan, H., \& Kasikci, Y. (2010). The application of traditional and alternative assessment and evaluation tools by teachers in social studies. Procedia - Social and Behavioral Sciences, 2, 4152-4156. https://doi.org/10.1016/j.sbspro.2010.03.656

Caracelli, J. V., \& Cooksy, L. (2013). Incorporating qualitative evidence in systematic reviews: Strategies and Challenges. Mixed methods and credibility of evidence in evaluation. New Directions for Evaluation, 138, 97-108. https://doi.org/10.1002/ev.20061 
Katherina GALLARDO. Competency-based assessment and the use of performance-based evaluation rubrics in higher education: Challenges towards the next decade

PROBLEMS

OF EDUCATION

IN THE $21^{\text {st }}$ CENTURY

Vol. 78 , No. 1, 2020

Carrillo, F. J. (2015). Knowledge-based development as a new economic culture. Journal of Open Innovation: Technology, Market, and Complexity, 1-17. https://doi.org/10.1186/s40852-0150017-5

Carson, L., \& Kavish, D. (2018). Scaffolding rubrics to improve student writing: Preliminary results of using rubrics in a sociology program to enhance learning and mechanical writing skills. Societies, 8(2), 34. https://doi.org/10.3390/soc8020034

Crespo-Martín, B., Figueras-Ferrer, E., Mascarella-Vilageliu, M., Nualart-Torroja, A., \& Valle-martí, M. R. J. A. (2016). Proyecto de investigación para la definición e implementación de rúbricas de evaluación de la competencia [Research project for the definition and implementation of competency assessment rubrics]. REIRE. Revista d'Innovaciói Recerca En Educació Recerca En Educació, 9(9 (1)), 62-87. https://doi.org/10.1344/reire2016.9.1915

Duckworth, A. L., \& Yeager, D. S. (2016). Measurement matters: Assessing personal qualities other than cognitive ability for educational purposes. Educational Research, 44(4), 237-251. https://doi. org/10.3102/0013189X15584327

Duran, R. A., Estay-niculcar, C., Alvarez, H., \& Randolph, J. (2015). Exploratory study about the implementation of the competency-based approach in graduate programs from two Panamanian universities. Journal of Hispanic Higher Education, 1(18), 1-18. https://doi. org/10.1177/1538192715612913

Ellis, L., Marston, C., Ph, D., Lightfoot, J., Ph, D., Sexton, J., \& Ph, D. (2015). Faculty professional development in student learning assessment: The Assessment Leadership Institute. Research \& Practice in Assessment, 10, 69-80. Retrieved from https://search.proquest.com/ docview/1829513087?pq-origsite $=$ gscholar

Elsevier. (2019). Analyze search results for Rubric along last decade using Scopus Index.

Escudero Escorza, T. (2016). Evaluation research in the 21st Century: A more and more relevant tool for the educational and social development. RELIEVE - Revista Electronica de Investigacion y Evaluacion Educativa, 22(1), 1-20. http://dx.doi.org/10.7203/relieve.22.1.8164

Eshun, E. F., \& Osei-Poku, P. (2013). Design students' perspectives on assessment rubric in studio-based learning. Journal of University Teaching \& Learning Practice, 10(1), 1-13. Retrieved from http:// ro.uow.edu.au/jutlp/vol10/iss1/8

Farris, K. B., Demb, A., Janke, K., Kelley, K., \& Scott, S. A. (2009). Assessment to transform competencybased curricula. American Journal of Pharmaceutical Education, 73(8), 1-14.

Gao, X., \& Grisham-Brown, J. (2011). The use of authentic assessment to report accountability data on young children's language, literacy and pre-math competency. International Education Studies, 4(2), 41-53. https://doi.org/10.5539/ies.v4n2p41

Gervais, J. (2016). The operational definition of competency-based education. The Journal of CompetencyBased Education, 1(2), 98-106. https://doi.org/10.1002/cbe2.1011

Goldberg, G. L. (2014). Revising an engineering design rubric: A case study illustrating principles and practices to ensure technical quality of rubrics. Practical Assessment, Research \& Evaluation, 19(8). Retrieved from http://pareonline.net/getvn.asp? $\mathrm{v}=19 \& \mathrm{n}=8$

Grubb, M. (1981). Using holistic evaluation (First). Encino, CA.: Glenco Publishing.

Hancock, D. (2007). Effects of performance assessment on the achievement and motivation of. Active Learning in Higher Education, 8(3), 219-231. https://doi.org/10.1177/1469787407081888

Hindriana, A. F., \& Setiawati, I. (2018). The development of authentic assessment rubric for assessing undergraduate students' learning and performance. Indonesian Journal of Learning and Instruction, 1(1), 21-28. https://doi.org/10.25134/ijli.v1i1.1279

Jin, S. H., Song, K. Il, Shin, D. H., \& Shin, S. (2015). A Performance-based evaluation rubric for assessing and enhancing engineering design skills in introductory engineering design courses. International Journal of Engineering Education, 31(4), 1007-1020. Retrieved from https://www.researchgate. net/profile/Sung_Hee_Jin/publication/282929432_A_Performance-Based_Evaluation_Rubric_ for_Assessing_and_Enhancing_Engineering_Design_Skills_in_Introductory_Engineering Design_Courses/links/5786009d08aec5c2e4e2c301.pdf

Jonsson, A. (2014). Rubrics as a way of providing transparency in assessment. Assessment and Evaluation in Higher Education, 39(7), 840-852. https://doi.org/10.1080/02602938.2013.875117

Jonsson, A., \& Svingby, G. (2007). The use of scoring rubrics: Reliability, validity and educational consequences. Educational Research Review, 2, 130-144. https://doi.org/10.1016/j. edurev.2007.05.002 
Katherina GALLARDO. Competency-based assessment and the use of performance-based evaluation rubrics in higher education: Challenges towards the next decade

PROBLEMS

OF EDUCATION IN THE $21^{\text {st }}$ CENTURY Vol. 78 , No. 1, 2020

78

Kan, A., \& Bulut, O. (2014). Crossed random-effect modeling: examining the effects of teacher experience and rubric use in performance assessments. Eurasian Journal of Educational Research, 14(57), 1-28. https://doi.org/10.14689/ejer.2014.57.4

Koh, K. H., Tan, C., \& Ng, P. T. (2012). Creating thinking schools through authentic assessment: The case in Singapore. Educational Assessment, Evaluation and Accountability, 24(2), 135-149. https:// doi.org/10.1007/s11092-011-9138-y

Kopp, M. L. (2018). A standardized clinical performance grading rubric: Reliability assessment. Journal of Nursing Education, 57(9), 544-548. https://doi.org/10.3928/01484834-20180815-06

Kuh, G. D., Jankowski, N., Ikenberry, S. O., \& Kinzie, J. L. (2014). Knowing what students know and can do: the current state of student learning outcomes assessment in U. S. Colleges and Universities. National Institute for Learning Outcomes Assessment. Retrieved from https:// learningoutcomesassessment.org/documents/2013\%20Survey\%20Report\%20Final.pdf

Lasater, K. (2006). Clinical judgment development: Using simulation to create an assessment rubric. Journal of Nursing Education, 46(11), 496-504. https://doi.org/10.3928/01484834-20071101-04

Latimer, M. E., Bergee, M. J., \& Cohen, M. L. (2010). Reliability and perceived pedagogical utility of a weighted music performance assessment rubric. Journal of Research in Music Education, 58(2), 168-183. https://doi.org/10.1177/0022429410369836

Lee, V. R., \& Fields, D. A. (2017). A rubric for describing competences in the areas of circuitry, computation, and crafting after a course using e-textiles. International Journal of Information and Learning Technology, 34(5), 372-384. https://doi.org/10.1108/IJILT-06-2017-0048

Mertler, C. A. (2001). Designing score rubrics for your classroom. Practical Assessment, Research and Evaluation, 7(25), 1-8. https://scholarworks.umass.edu/pare/vol7/iss1/25

Meyer-Adams, N.; Potts, M. K.; Koob, J.; Dorsey, C. J.; Rosales, A. M. (2011). How to tackle the shift of the educational assessment from learning outcomes to competencies: one program's transition. Journal of Social WorkEducation, 47(3), 489-508. https://doi.org/10.5175/JSWE.2011.201000017

O'Brien, C. E., Franks, A. M., \& Stowe, C. D. (2008). Multiple rubric-based assessments of student case presentations. American Journal of Pharmaceutical Education, 72(3), 1-7. https://doi. org/10.5688/aj720358

Panadero, E., \& Jonsson, A. (2013). The use of scoring rubrics for formative assessment purposes revisited: A review. Educational Research Review, 9, 129-144. https://doi.org/10.1016/j. edurev.2013.01.002

Reddy, Y. M., \& Andrade, H. (2010). A review of rubric use in higher education. Assessment \& Evaluation in Higher Education, 35(4), 435-448. https://doi.org/10.1080/02602930902862859

Rodriguez, I., \& Gallardo, K. (2017). Redesigning an educational technology course under a competency-based performance assessment model. Pedagogika, 127(3), 186-204. http://dx.doi. org/10.15823/p.2017.48

Roy, G. (2016). Competency-based Assessment in Primary Education in Bangladesh-A Review. Retrieved from https://ssrn.com/abstract=2899109 or http://dx.doi.org/10.2139/ssrn.2899109

Schoepp, K., Danaher, M., \& Kranov, A. A. (2018). An effective rubric norming process. Practical Assessment, Research \& Evaluation, 23(11), 1-12. https://scholarworks.umass.edu/pare/vol23/ iss $1 / 11$

Slaus, I. (2013). Entering global knowledge society: Role of education. Donald School. Journal of Ultrasound in Obstetrics and Gynecology, 7, 239-247. https://doi.org/10.5005/jpjournals-10009-1289

Smit, R., Bachmann, P., Blum, V., Birri, T., \& Hess, K. (2017). Effects of a rubric for mathematical reasoning on teaching and learning in primary school. Instructional Science, 45(5), 603-622. https://doi.org/10.1007/s11251-017-9416-2

Tigelaar, D., \& Janssen, F. (2012). Dilemmas in designing rubrics for the assessment of student teachers in teacher education: Stories of a design and evaluation process in the context of biology teaching. Educación Química, 23(2), 179-187. https://doi.org/10.1016/S0187-893X(17)30106-4

Velasco-Martínez, L. C., \& Hurtado, J. C. T. (2018). The use of rubrics in higher education and competences evaluation. Profesorado, 22(3), 183-208. https://doi.org/10.30827/profesorado.v22i3.7998 
Katherina GALLARDO. Competency-based assessment and the use of performance-based evaluation rubrics in higher education: Challenges towards the next decade

PROBLEMS

OF EDUCATION

IN THE $21^{\text {st }}$ CENTURY

Vol. 78 , No. 1,2020

Verano-Tacoronte, D., González-Betancor, S. M., Bolívar-Cruz, A., Fernández-Monroy, M., \& GalvánSánchez, I. (2016). Valoración de la competencia de comunicación oral de estudiantes universitarios a través de una rúbrica fiable y válida [Assessment of the oral communication competence of university students through a reliable and valid rubric]. Revista Brasileira de Educação, 21(64), 39-60. https://doi.org/10.1590/S1413-24782016216403

Voronov, M., Chasovskykh, V., Popov, V., Anyanova, E., \& Krainova, T. (2015). Effectiveness research of the new learning elements initiated by the change to competency-based education model in Russia. Procedia - Social and Behavioral Sciences, 214, 758-768. https://doi.org/10.1016/j. sbspro.2015.11.712

Yune, S. J., Lee, S. Y., Im, S. J., Kam, B. S., \& Baek, S. Y. (2018). Holistic rubric vs. analytic rubric for measuring clinical performance levels in medical students. BMC Medical Education, 18(1), 1-6. https://doi.org/10.1186/s12909-018-1228-9

Received: October 31, 2019

Accepted: January 18, 2020

Cite as: Gallardo, K. (2020). Competency-based assessment and the use of performancebased evaluation rubrics in higher education: Challenges towards the next decade. Problems of Education in the $21^{\text {st }}$ Century, 78(1), 61-79. https://doi.org/10.33225/pec/20.78.61

Katherina Gallardo
Dr., Director of Educational Innovation Ph.D. Program, School of Humanities and Education, Monterrey Institute of Technology and Higher Education, Av. Eugenio Garza Sada 2501 Sur. Colonia Tecnologico, Mexico.

E-mail: katherina.gallardo@tec.mx

Website: https://itesm.academia.edu/KatherinaGallardo ORCID: https://orcid.org/0000-0001-8343-9518 